\title{
Article \\ The Structure Design and Photoelectric Properties of Wideband High Absorption Ge/GaAs/P3HT:PCBM Solar Cells
}

\author{
Xintao Zeng, Ning Su and Pinghui Wu*
}

Fujian Provincial Key Laboratory for Advanced Micro-Nano Photonics Technology and Devices \& Key Laboratory of Information Functional Material for Fujian Higher Education, Quanzhou Normal University, Quanzhou 362000, China; liubin@lyu.edu.cn (X.Z.); qsz20211397@student.fjnu.edu.cn (N.S.)

* Correspondence: phwu@zju.edu.cn; Tel./Fax: +86-0595-22003815

check for updates

Citation: Zeng, X.; Su, N.; Wu, P. The Structure Design and Photoelectric Properties of Wideband High Absorption Ge/GaAs/P3HT:PCBM Solar Cells. Micromachines 2022, 13, 349. https://doi.org/10.3390/ mi13030349

Academic Editor: Hugo Aguas

Received: 13 January 2022

Accepted: 14 February 2022

Published: 23 February 2022

Publisher's Note: MDPI stays neutral with regard to jurisdictional claims in published maps and institutional affiliations.

Copyright: (C) 2022 by the authors. Licensee MDPI, Basel, Switzerland. This article is an open access article distributed under the terms and conditions of the Creative Commons Attribution (CC BY) license (https:// creativecommons.org/licenses/by/ $4.0 /)$.

\begin{abstract}
Using the finite-difference time-domain (FDTD) method, we designed an ultra-thin Ge/GaAs/P3HT:PCBM hybrid solar cell (HSC), which showed good effects of ultra-wideband $(300 \mathrm{~nm}-1200 \mathrm{~nm})$, high absorption, and a short-circuit current density of $44.7 \mathrm{~mA} / \mathrm{cm}^{2}$. By changing the thickness of the active layer P3HT:PCBM, we analyzed the capture of electron-hole pairs. We also studied the effect of $\mathrm{Al}_{2} \mathrm{O}_{3}$ on the absorption performance of the cell. Through adding metal $\mathrm{Al}$ nanoparticles (Al-NPs) and then analyzing the figures of absorption and electric field intensity, we found that surface plasma is the main cause of solar cell absorption enhancement, and we explain the mechanism. The results show that the broadband absorption of the solar cell is high, and it plays a great role in capturing sunlight, which will be of great significance in the field of solar cell research.
\end{abstract}

Keywords: hybrid solar cell; Ge/GaAs/P3HT:PCBM; localized surface plasmon; photon absorption; FDTD

\section{Introduction}

With the increasing shortage of coal, oil, and natural gas and the strong support of new energy, solar energy, as a clean and pollution-free renewable energy with rich resources, has become a hot research topic among scholars [1-4]. Although silicon is the most widely used commercial material for solar cells [5,6], GaAs has its own advantages. GaAs bandgap is $1.42 \mathrm{eV}$, and $\mathrm{Si}$ bandgap is $1.12 \mathrm{eV}$. GaAs has a high electron mobility, up to $8000 \mathrm{~cm}^{2} / \mathrm{V} \cdot \mathrm{s}$; the electron mobility of silicon is $1350 \mathrm{~cm}^{2} / \mathrm{V} \cdot \mathrm{s}$. Thus, GaAs has a wider bandgap and higher absorption coefficient than Si. A photoactive layer of several microns is enough to use the transmitted light, because of the direct band gap in GaAs as compared to Si or other semiconductor materials. Moreover, GaAs is widely studied in solar cells because of its high electron saturation rate and electron mobility [7]. Pham et al. designed a positive $\mathrm{ZnO}$ electronic-selective contact single-junction $\mathrm{GaAs}$ cell with a current density of $30.48 \mathrm{~mA} / \mathrm{cm}^{2}$ [8]. In order to reduce the substrate cost, GaAs solar cells usually have Ge as the substrate material [9-11]. Ge is commonly used in the wafer substrates of high-efficiency multi-junction photovoltaic cells for space applications [12,13]. In addition, Ge and GaAs have similar lattice constants; their lattice constants are 5.646 and 5.653, thus avoiding excessive lattice imperfection from being introduced on the back surface [14]. There are Mars rovers and several satellites that use three-junction GaAs on Ge cells. Thus, Ge substrate is utilized to manufacture GaAs solar cells [15]. A good passivation layer is essential for solar cells. $\mathrm{Al}_{2} \mathrm{O}_{3}$, with excellent field-effect passivation properties and good chemical passivation properties, has been widely studied as a possible gate oxide of GaAs [16], which plays a certain role in improving the efficiency of solar cells. Polymer material P3HT:PCBM has improved carrier mobility, so we combined polymer materials and semiconductor materials to form a hybrid solar cell.

In addition to adding passivation layers, there are many ways to improve the efficiency of solar cells, such as nanomaterials [17,18], anti-reflection films $[19,20]$, surface 
texture [21,22], etc. Among them, metal nanostructures have been widely studied in the field of solar cells due to their unique properties of enhancing electric fields and improving light absorption [23-25]. They use the local electromagnetic field near the metal surface to amplify and produce local surface plasmons (LSPs) at the interface between metal nanoparticles and semiconductor materials [26-28]. The electromagnetic wave propagated by LSPs along with the interface of the metal back contact and semiconductor absorption layer can effectively capture and conduct incident light in the semiconductor layer [29]. Ding Dong et al. studied the light absorption of microcrystalline silicon thin film solar cells enhanced by $\mathrm{Al}$ nanoparticles, and obtained different ratios of radii and periods, resulting in different surface plasmon resonance effects [30]. Different sizes, shapes, and arrangements of metal nanoparticles affect the excitation of these excitons and thus the absorption of solar cells [31-33]. Gurjit Singh et al. discussed the absorption enhancement effect of copper particles with sizes of 40-200 nm on GaAs solar cells. They also discussed the effect of Al nanoparticles with different sizes on the front and back surfaces to enhance the surface plasmon absorption of GaAs solar cells based on surface plasmon absorption [34,35]. For this reason, we performed a detailed study and analysis of the metal nanoparticles of the HSC.

In this paper, we use FDTD Solutions to simulate the Ge-based GaAs-P3HT:PCBM HSC based on Al-NPs. By introducing the spherical Al-NPs model based on FDTD, it is found that LSP is the main reason for the enhancement of solar cell light absorption, and its mechanism is analyzed. It is shown that this three-dimensional Al-NPs optical model is very useful for understanding the light absorption behavior of Al-NPs in solar cells varying with wavelength and shape parameters. We also studied the absorption characteristics of the organic active layer of P3HT:PCBM deposited on the GaAs surface to analyze the specific mechanism.

\section{Structure Design and Numerical Model}

The structure of the cell is shown in Figure 1. Ag is the backplate, and Ge is the substrate to produce the plasma plasmon metal aluminum nanoparticles of the GaAsP3HT:PCBM hybrid solar cell. The Ag layer thickness is $200 \mathrm{~nm}$, and the Ge layer thickness is $450 \mathrm{~nm}$. The thickness of the GaAs cylinder is $400 \mathrm{~nm}$, with a radius of $120 \mathrm{~nm}$. The thickness of P3HT:PCBM of the cylinder is $60 \mathrm{~nm}$ to capture photons, and the thickness of $\mathrm{Al}_{2} \mathrm{O}_{3}$ as the gate oxidant is $30 \mathrm{~nm}$ to protect it. Since the FDTD calculation can only be carried out in a limited area, periodic boundary conditions are set on edges of $\mathrm{x}$ and $\mathrm{y}$ to avoid the generation of reflected waves, and a high matching layer (PML) [36] is used at the top and bottom of the $z$-axis. The plane-wave excitation source is placed directly above the model to simulate the solar light source, and a reflective power monitor and transmission power monitor are placed to calculate the reflectivity $R$ and transmittance $T$, respectively. According to $\mathrm{A}=1-\mathrm{R}-\mathrm{T}$, the absorption rate of the battery can be obtained [37]. The current density value can be calculated by setting the analytical photon production rate.

FDTD Solutions was used to simulate the solar cell. The FDTD method, proposed by Kane Yee [38,39], is a differential differentiation of Maxwell equations in time and space. The electric field and magnetic field are calculated alternately in the space domain and updated in the time domain to simulate the change of electromagnetic field, to achieve the purpose of numerical calculation $[40,41]$. PML is used for special processing in the limited space so that the internal field does not produce distortion. The carrier generation rate can be calculated with FDTD, and its expression is $[42,43]$

$$
G(\vec{r})=\frac{P_{a b s}(\vec{r}, \omega)}{\hbar \omega}=\frac{-0.5|E(\vec{r}, \omega)|^{2} \operatorname{Im}[\varepsilon(\vec{r}, \omega)]}{\hbar}
$$

$P_{a b s}$ is the absorption space power density, and its expression is [42]

$$
P_{a b s}(\lambda)=-0.5 \omega|E(\lambda)|_{2} \operatorname{Im}[\varepsilon(\lambda)]
$$


where $\omega$ is the angular frequency, $E$ is the electric field intensity, $\varepsilon$ is the permittivity, and $\hbar \omega$ is the energy of a photon. The FDTD software then calculates the short-circuit current density directly:

$$
J_{s c}=\frac{e}{\hbar c} \int_{300 \mathrm{~nm}}^{1200 \mathrm{~nm}} Q E(\lambda) \lambda I_{A M 1.5}(\lambda) d \lambda
$$

where $\hbar$ is reduced Plank's constant, $c$ is the speed of light in the free space, $Q E$ is the Quantum Efficiency of Solar Cell, and $I_{A M 1.5}$ is the AM1.5 solar spectrum [44].

(a)

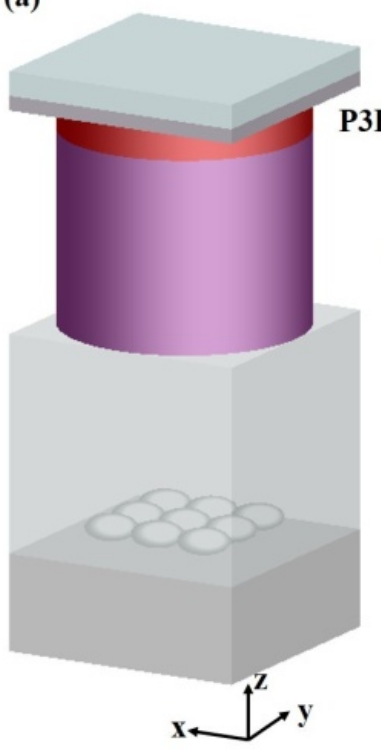

(b)

$\mathrm{SiO}_{2}$

$\mathrm{Al}_{2} \mathrm{O}_{3}$

PHT:PCBM

GaAs

Ge

Al

Ag

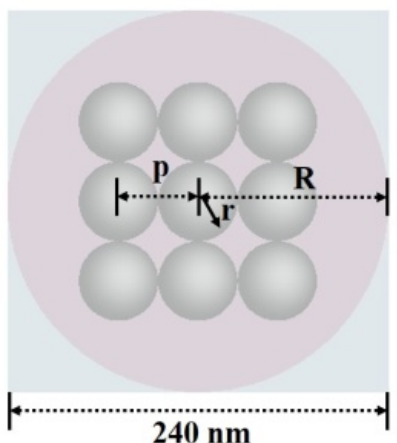

Figure 1. (a) HSC 3D diagram. (b) Plan of HSC in the $x-y$ plane.

\section{Simulation Results and Discussion}

AM1.5 is the average illumination of sunlight incident on the earth's surface, and its total solar radiation is $100 \mathrm{~mW} / \mathrm{cm}^{-2}$ [45]. The light absorption rate of the solar cell designed after optimization is shown in Figure 2a. Within $300 \mathrm{~nm}-1200 \mathrm{~nm}$, the light absorption rate of the cell is above $90 \%$, and most of the light absorption is above $95 \%$, which can be approximated to the high absorption of broadband. Figure $2 b$ shows the absorption spectrum of the cell under the standard spectrum AM1.5, and the absorption spectrum of the cell is very close to the curve of AM1.5. Figure 2 shows that the solar cell has a good absorption of sunlight and can capture photon energy well, thus improving the conversion efficiency of the cell from the source $[46,47]$.

(a)

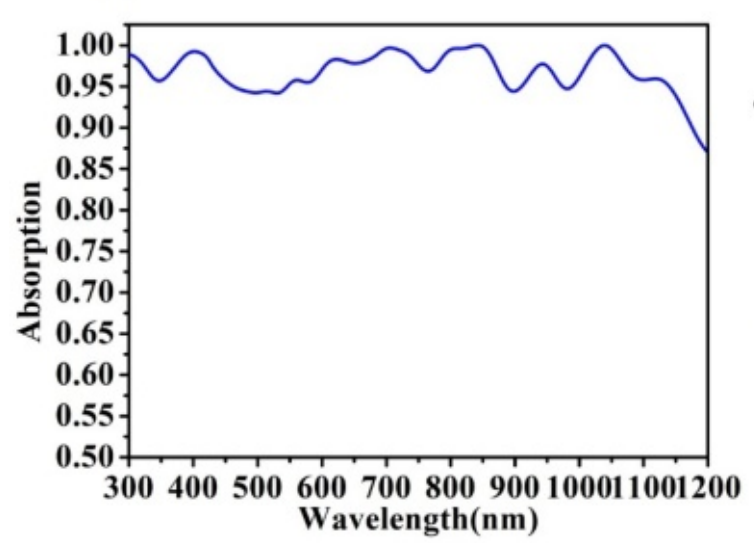

(b)

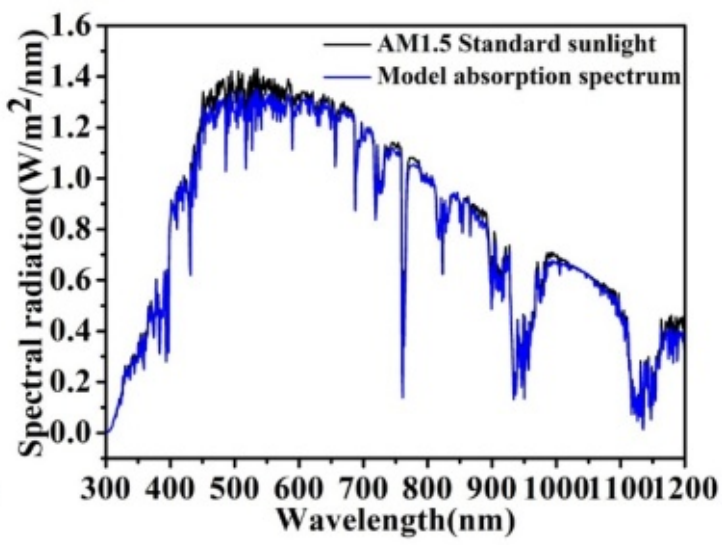

Figure 2. (a) HSC absorption curve; (b) AM1.5 standard sunlight, and the HSC absorption spectra. 
Figure 3 shows the electric field intensity at three values of the highest absorption rate: $\lambda 1, \lambda 2$, and $\lambda 3$. Figure $3 \mathrm{a}-\mathrm{c}$ reflects the electric field intensity of the longitudinal section $\mathrm{z}$ from $200 \mathrm{~nm}$ to $1190 \mathrm{~nm}$, that is, the electric field intensity of the $\mathrm{y}-\mathrm{z}$ plane. The electric field intensity gradually increases from left to right. When $\lambda 1=400 \mathrm{~nm}$, the electric field intensity of the structure remains unchanged. In Figure $3 b, c$, the longer wave, because of its stronger diffraction ability, after the part is absorbed by the material energy; the residual electromagnetic energy had a deeper extrinsic absorption, producing the electric field intensity distribution in the graph. The light spread resulted in the light carrier moving up, making the electric field enhancement red. From Figure $3 b, \lambda 2=806 \mathrm{~nm}$, and from Figure $3 c$, $\lambda 3=1030 \mathrm{~nm}$, showing that the electric field intensity between GaAs and P3HT:PCBM is enhanced. A high electric field will speed up the transport between electrons and holes and avoid electron-hole recombination [48]. We can see that there is obvious diffraction enhancement in the bottom layer, which is the result of surface plasma element interaction. Figure $3 \mathrm{~d}-\mathrm{f}$ reflects the cross-section at $\mathrm{z}=200 \mathrm{~nm}$ and the electric field intensity on the $x-y$ plane. As can be seen from the figure, Al-NPs interact with the medium to produce the plasma plasmon, which strengthens the electric field vibration [49].

(a)

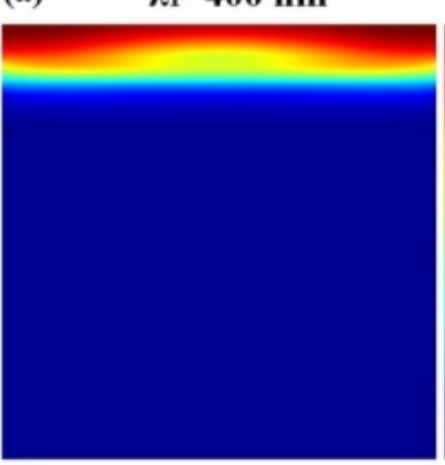

(d)

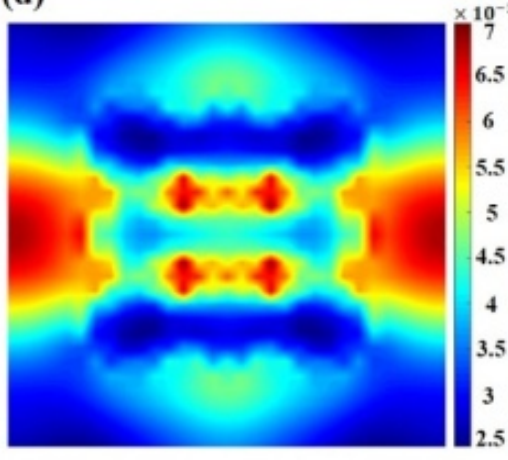

(b)

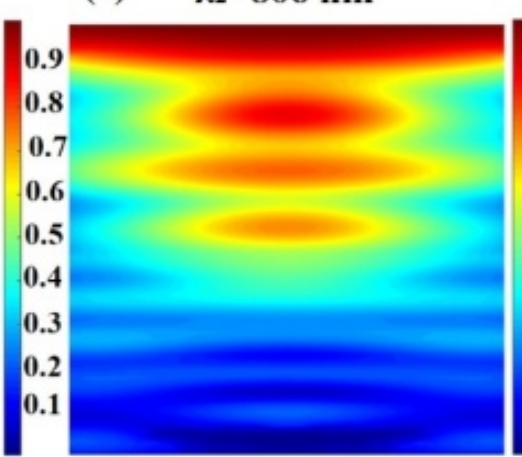

(e) (c) $\quad \lambda_{3}=1030 \mathrm{~nm}$

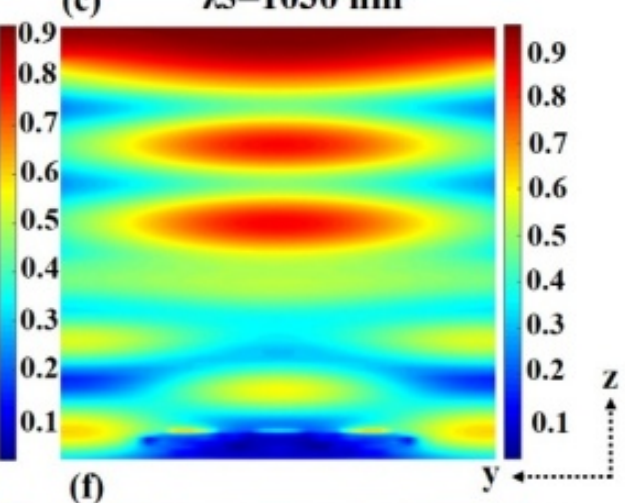

(f)
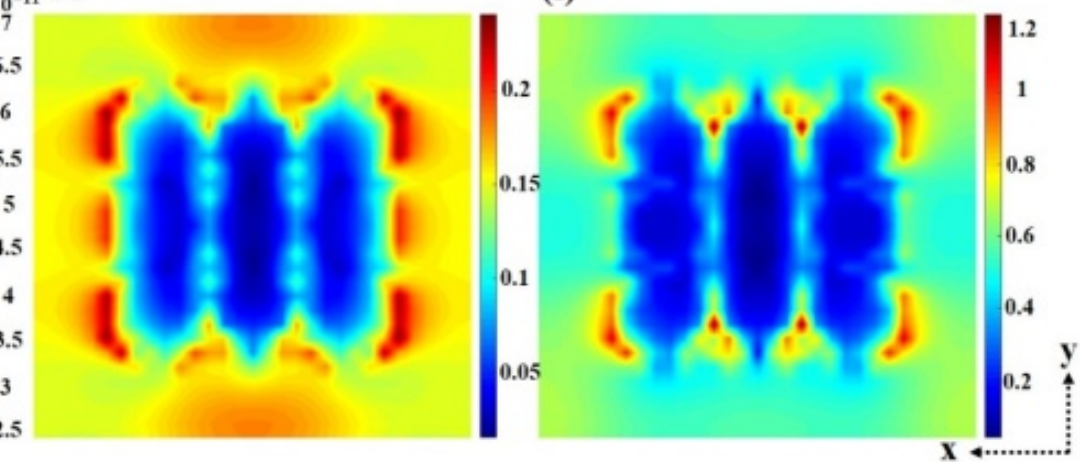

Figure 3. The electric field distribution in the $y-z$ plane at three wavelengths: (a) $400 \mathrm{~nm}$, (b) $806 \mathrm{~nm}$, (c) $1030 \mathrm{~nm}$, with an absorption intensity greater than $97 \%$. The electric field action of Al-NPs in the $\mathrm{x}-\mathrm{y}$ plane at three wavelengths: (d) $400 \mathrm{~nm}$, (e) $806 \mathrm{~nm}$, (f) $1030 \mathrm{~nm}$.

Figure 4 shows the influence of the thickness of P3HT:PCBM on the absorption and current density of the solar cell. P3HT:PCBM has chemical stability and high crystallinity carrier mobility and absorption, and it is the most commonly used material applied to organic photovoltaics (OPVs) [50]. Compared with the absence of P3HT:PCBM(h the addition of P3HT:PCBM enhanced the cell absorption at 300 to $500 \mathrm{~nm}$ and 850 to $1050 \mathrm{~nm}$. With the increase of $\mathrm{h}_{\mathrm{P} 3 \mathrm{HT}: \mathrm{PCBM}}$, the photon absorption rate increases gradually. When $\mathrm{h}_{\mathrm{P} 3 \mathrm{HT}: \mathrm{PCBM}}=60 \mathrm{~nm}$, the photon absorption rate is increased. However, when $\mathrm{h}$ increases again, the absorption rate of photons decreases between 800 and $900 \mathrm{~nm}$, indicating that the excessively thick P3HT:PCBM hinders the transmission of photons and affects the absorption rate of solar cells. The current density JSC increases first and then decreases with the increase of $\mathrm{h}_{\mathrm{P} 3 \mathrm{HT}} \mathrm{PCBM}$, indicating that the thickness of P3HT:PCBM has an influence on 
the ability of electron and hole transport, and excessive thickness will hinder the transport of electrons and holes. Therefore, we chose a P3HT:PCBM thickness $\mathrm{h}_{\text {P3HT:PCBM }}$ of $60 \mathrm{~nm}$ as the optimal parameter to increase the photon absorption effect for the cell.

(a)

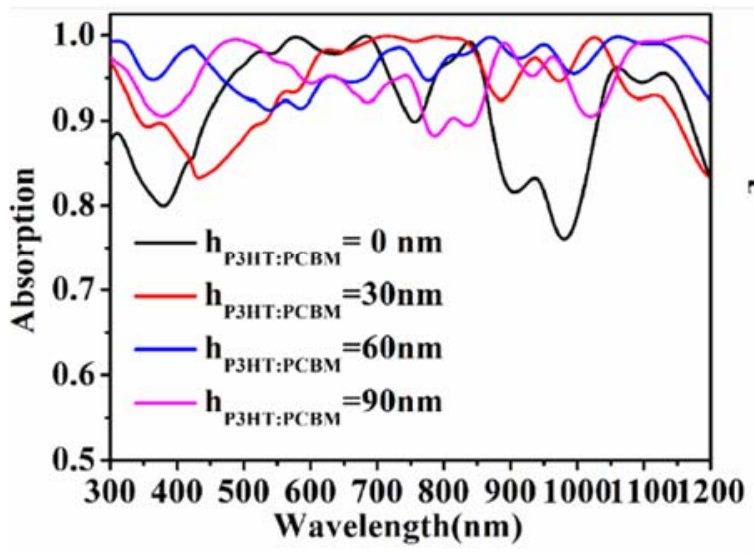

(b)

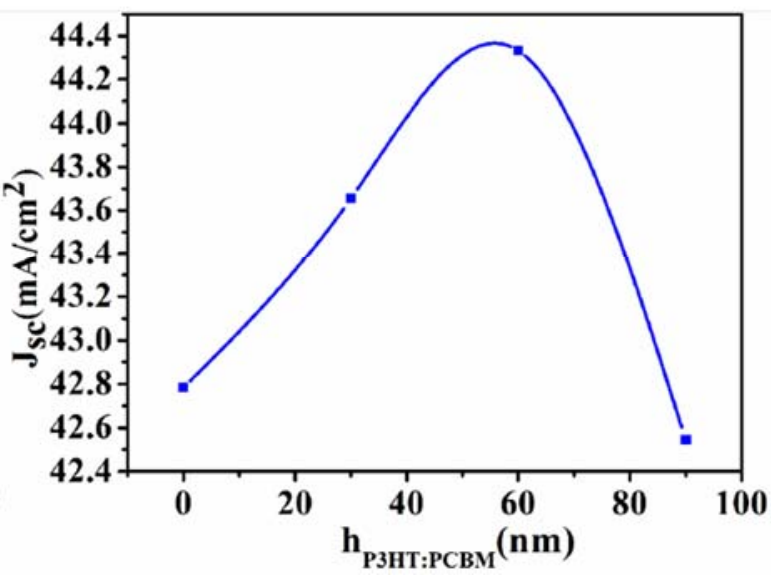

Figure 4. Effect of different P3HT:PCBM thicknesses on light absorption (a) and current density (b).

Figure 5 describes the influence of $\mathrm{Al}_{2} \mathrm{O}_{3}$ on the performance of the cell. As a reflection reducing layer, $\mathrm{Al}_{2} \mathrm{O}_{3}$ is often placed on the surface of $\mathrm{GaAs}$ to reduce reflection and increase absorption. Compared with the cells without $\mathrm{Al}_{2} \mathrm{O}_{3}\left(\mathrm{i}_{\mathrm{Al} 2 \mathrm{O}}=0 \mathrm{~nm}\right)$, the cells with the $\mathrm{Al}_{2} \mathrm{O}_{3}$ anti-reflection layer have absorption enhancement in the near-infrared band. It reduces the reflection of photons and allows more of the photon energy to be injected into the cell, thus increasing absorption. With the increase of $\mathrm{i}_{\mathrm{Al} 2 \mathrm{O} 3}$, the absorption of the near-infrared band gradually increases, but at the same time, the absorption of the visible band gradually decreases. The results show that the anti-reflection effect of $\mathrm{Al}_{2} \mathrm{O}_{3}$ gradually moves to the infrared band with the increase of its thickness, and it can increase the absorption of long wavelengths. With the increase of the thickness of $\mathrm{Al}_{2} \mathrm{O}_{3}$, the field passivation effect is significant and the collecting efficiency of the carrier is improved; thus, the short-circuit current is increased. When the thickness of $\mathrm{Al}_{2} \mathrm{O}_{3}$ is too high, the minority carrier life is not enough to support the carrier transmission, and the current density decreases [51]. Therefore, the $\mathrm{i}_{\mathrm{Al} 2 \mathrm{O} 3}=30 \mathrm{~nm}$ anti-reflection layer was selected to improve the overall performance of the HSC.

(a)

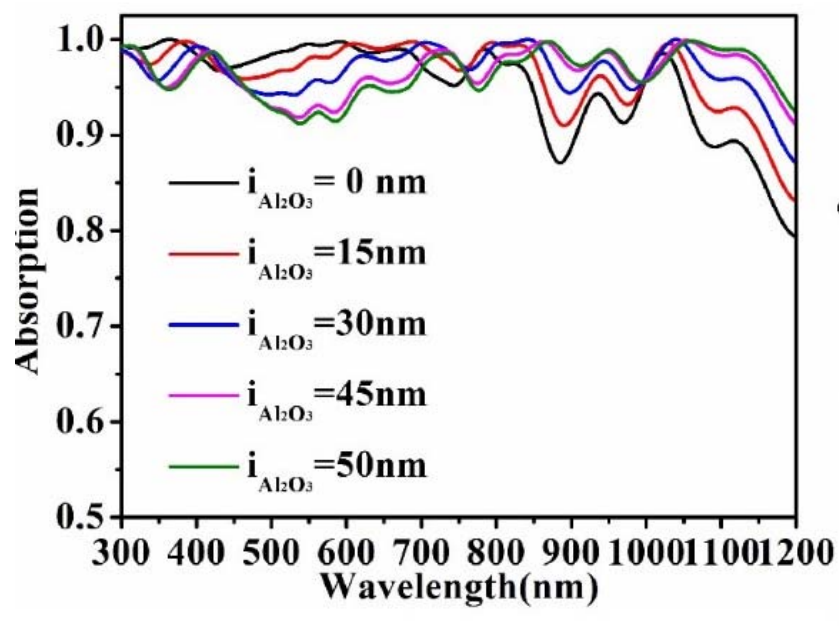

(b)

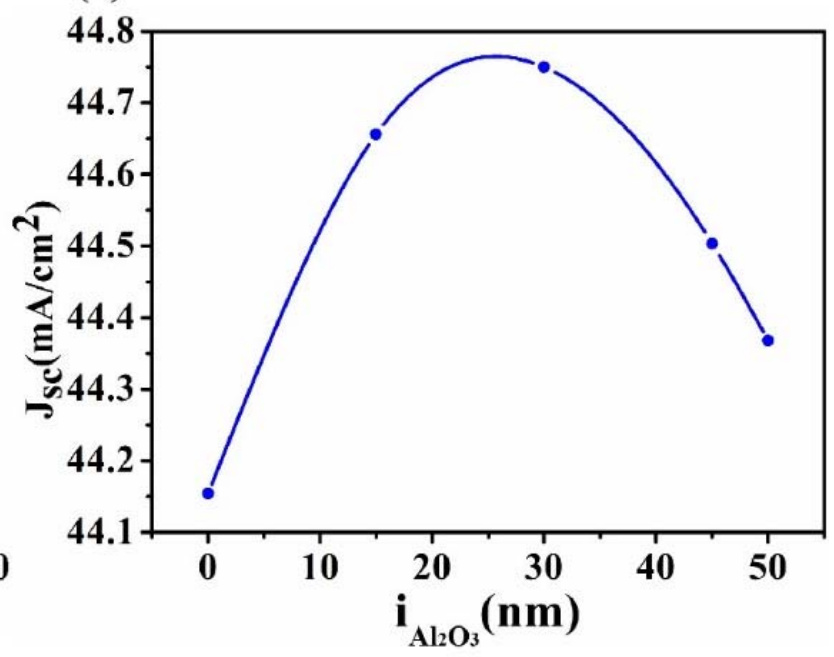

Figure 5. Absorption (a) and current density (b) of $\mathrm{Al}_{2} \mathrm{O}_{3}$ with different thickness ( $\mathrm{h}_{\mathrm{P} 3 \mathrm{HT}} \mathrm{PCBM}=60 \mathrm{~nm}$ ). 
In Figure 6a, in the visible band, the thickness of GaAs has little influence on light absorption. The absorption properties of GaAs in the near-infrared band are different with the change of thickness. In Figure $6 \mathrm{~b}$, the current density is the highest when $\mathrm{M}_{\mathrm{GaAs}}=400 \mathrm{~nm}$. As $\mathrm{M}_{\mathrm{GaAs}}$ continues to increase, the electron and hole transport distance in GaAs is longer, and the current density decreases. Therefore, $400 \mathrm{~nm}$ thick GaAs was selected as the optimal parameter. Figure 6c plots the absorption of the GaAs radius to the solar cell. The larger the radius, the stronger the absorption capacity, especially in the 700-1200 nm band. JSC shows an upward trend with the increase of $\mathrm{R}_{\mathrm{GaAs}}$, as shown in Figure $6 \mathrm{~d}$. The larger radius can make the carrier transport capacity in the semiconductor stronger and avoid the recombination of electron hole pairs in the small region, and thus can improve the short-circuit current density. Therefore, when the radius of GaAs of the cylinder is $\mathrm{R}_{\mathrm{GaAs}}=120 \mathrm{~nm}$ and the thickness is $\mathrm{M}_{\mathrm{GaAs}}=400 \mathrm{~nm}$, the absorption effect and current density are the best.

(a)

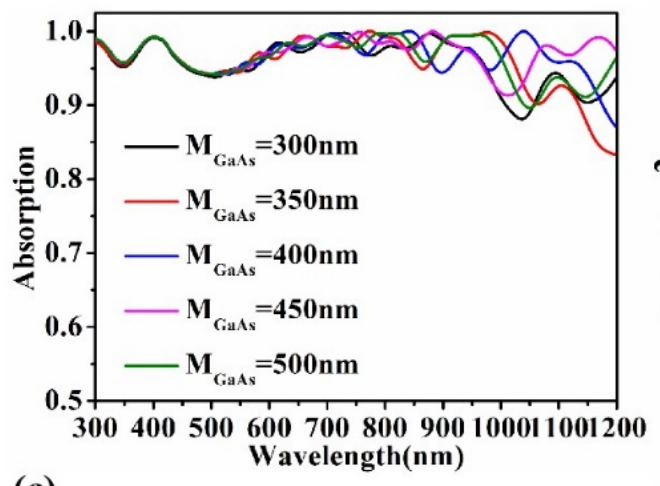

(c)

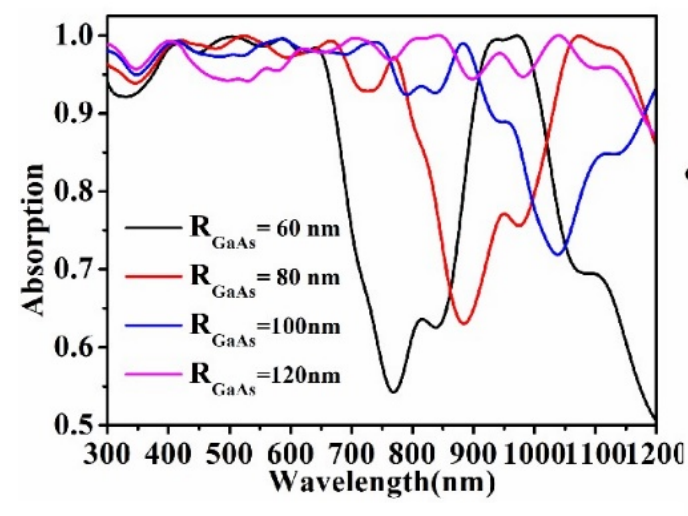

(b)
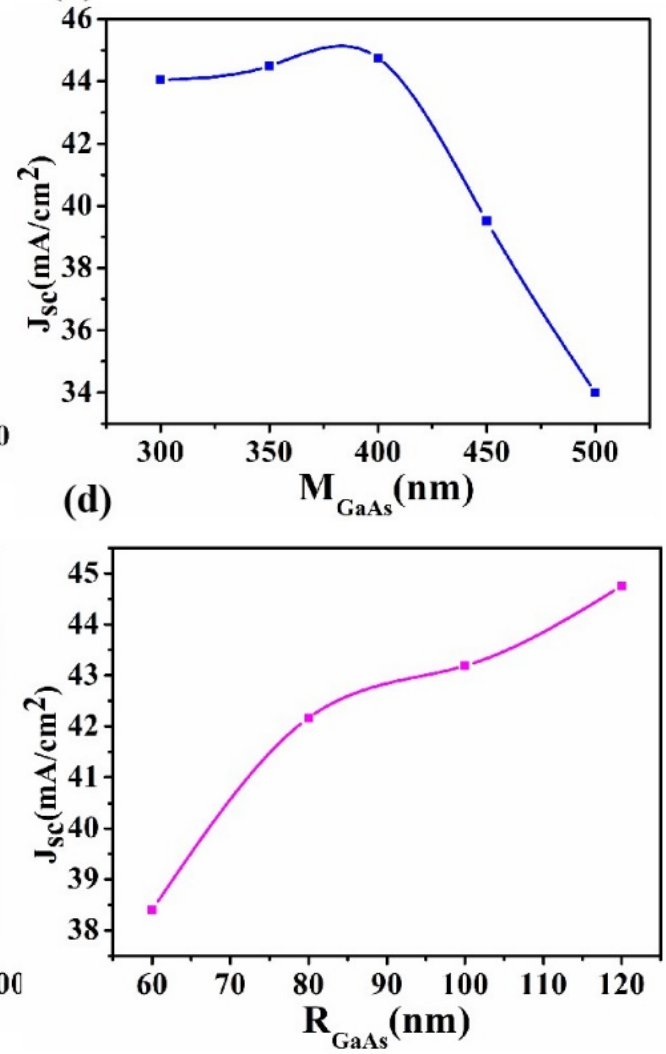

Figure 6. Changes in absorption (a) and current density (b) with GaAs thickness. Diagram of changes in absorption (c) and current density (d) caused by cylindrical GaAs radius ( $\mathrm{h}_{\text {P3HT:PCBM }}=60 \mathrm{~nm}$, $\left.\mathrm{i}_{\mathrm{Al} 2 \mathrm{O} 3}=30 \mathrm{~nm}\right)$.

Because the interface between the metal and the medium will produce plasma plasmons, the action of electromagnetic wave and electromagnetic field will be changed, so we explored the influence of the size and spacing of Al-NPs on the solar cell (see Figure 7). In Figure $7 \mathrm{a}$, with the increase of radius $\mathrm{r}_{\mathrm{Al}-\mathrm{NPs}}$, the light absorption rate of the cell gradually increases in the near-infrared band. The results show that the absorption of Al nanoparticles increases obviously in the long wavelength band. Figure $7 \mathrm{~b}$ shows that JSC increases first and then decreases with the increase of $\mathrm{r}_{\mathrm{Al}-\mathrm{NPs}}$, and its maximum value is around $\mathrm{r}_{\mathrm{Al}-\mathrm{NPs}}=25 \mathrm{~nm}$. Because the particle size of Al nanoparticles has a great influence on the spectral absorption rate of the cell surface in the near infrared band, the lower the absorption rate is, the fewer the photons that are captured and the fewer the electrons that are transmitted, resulting in a lower current density [52,53]. Figure 7c shows the effect 
of $\mathrm{p}_{\mathrm{Al}-\mathrm{NPs}}$ differences in the centroid spacing between two Al-NPs. In general, spacing $\mathrm{p}$ has little influence on the light absorption rate of the cell, but a great influence on the current density. As can be seen from Figure $7 \mathrm{~d}$, when the two spheres are close to each other $\left(\mathrm{p}_{\mathrm{Al}-\mathrm{NPs}}=50 \mathrm{~nm}\right)$, the effect is the strongest and the current density is the largest.

(a)

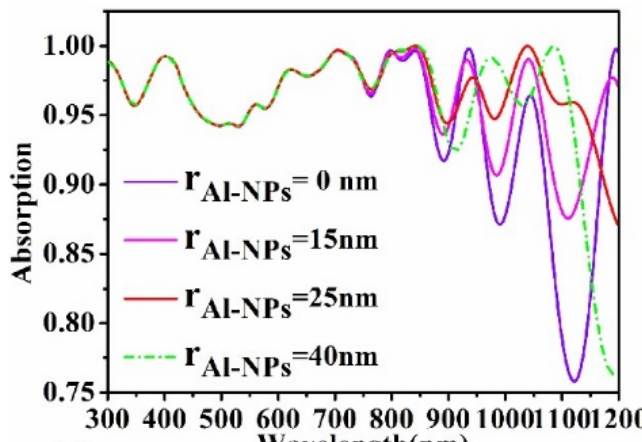

(c)

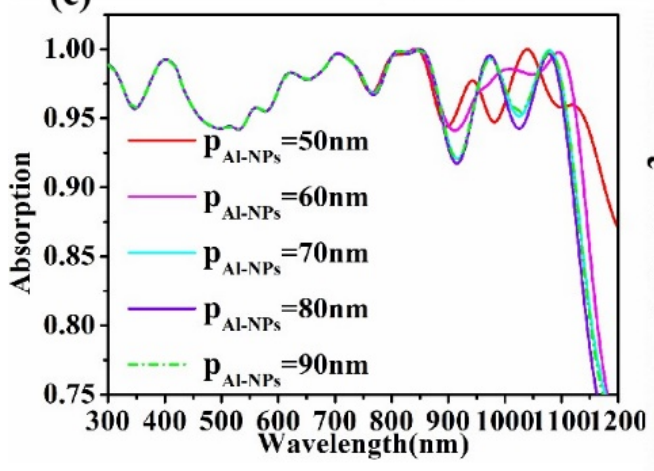

(b)
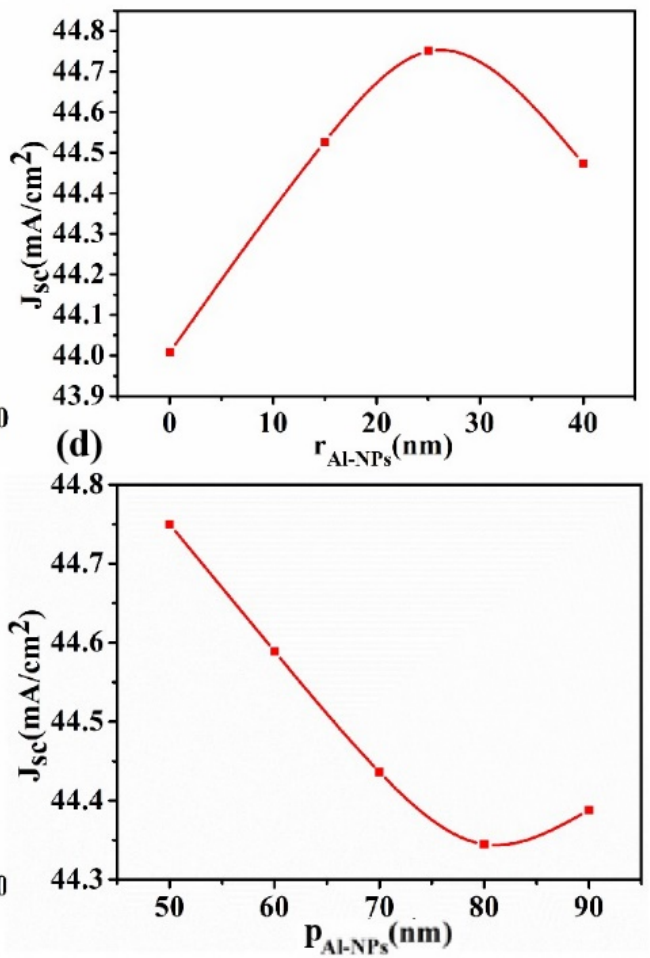

Figure 7. Changes in absorption (a) and current density (b) due to different sizes of Al-NPs. Influence diagram of solar cell absorption (c) and current density (d) caused by Al-NPs spherical center spacing $\left(\mathrm{h}_{\mathrm{P} 3 \mathrm{HT}: \mathrm{PCBM}}=60 \mathrm{~nm}, \mathrm{i}_{\mathrm{Al} 2 \mathrm{O} 3}=30 \mathrm{~nm}, \mathrm{M}_{\mathrm{GaAs}}=400 \mathrm{~nm}, \mathrm{R}_{\mathrm{GaAs}}=120 \mathrm{~nm}\right)$.

Figure 8 shows the electric field diagram of the spherical spacing between two aluminum particles at $\lambda=1030 \mathrm{~nm}$. Figure $8 \mathrm{a}-\mathrm{e}$ is the electric field diagram on the $\mathrm{y}-\mathrm{z}$ plane of the longitudinal section. When $\mathrm{p}_{\mathrm{Al}-\mathrm{NPs}}=50 \mathrm{~nm}$, the effect between adjacent aluminum spheres intensifies the electric field vibration, and the electric field intensity is the highest, which is the highest consistent with the absorption rate in Figure 7c. Figure 8f-j is the electric field diagram of the cross-section $x-y$ plane at the center of the Al-NPs. It shows the excitation of LSP near the Al as a function of the spacing between the Al-NPs. In Figure $8 \mathrm{f}$, the adjacent $\mathrm{Al}$ spheres generate a strong electric field and propagating waves, which spread around to enhance light absorption and thus increase the photocurrent. In Figure $8 \mathrm{~g}-\mathrm{f}$, the $\mathrm{Al}$ spheres are not adjacent and only produce plasmons locally, with a very small acting region. In Figure $8 \mathbf{j}$, due to the distance, the electric field oscillation effect is not strong, resulting in a weak electric field. 
(a) $\mathbf{p}_{\mathrm{Al}-\mathrm{NPs}}=\mathbf{5 0} \mathrm{nm}$

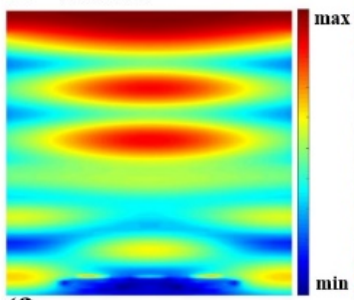

(f)

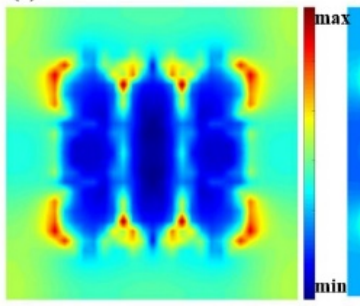

(b) $\mathrm{p}_{\mathrm{Al}-\mathrm{NPs}}=60 \mathrm{~nm}$

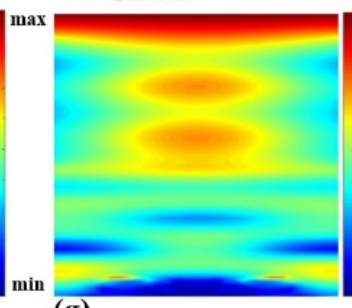

(g) (c) $\mathbf{p}_{\mathrm{Al}-\mathrm{NPs}}=70 \mathrm{~nm}$

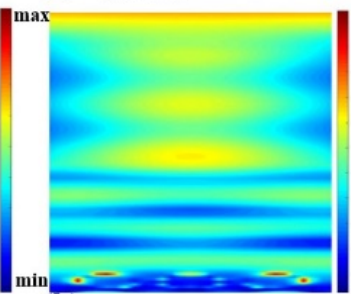

(h) (d) $\mathrm{p}_{\mathrm{Al}-\mathrm{NPs}}=\mathbf{8 0} \mathrm{nm}$

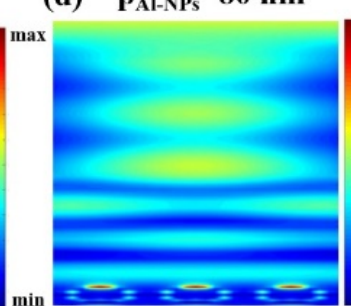

(i) (e) $\quad p_{\text {Al-NPs }}=90 \mathrm{~nm}$

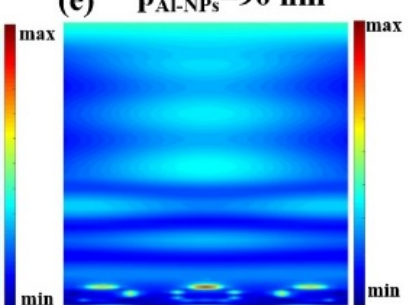

(j)

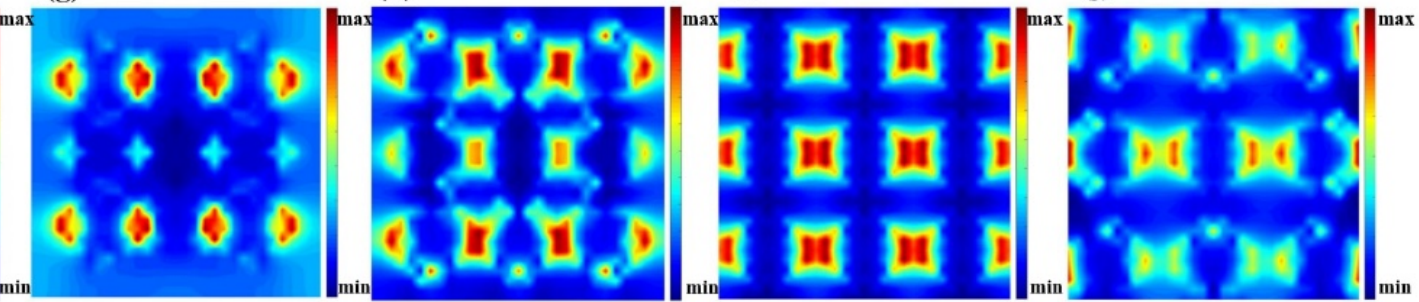

Figure 8. The electric field of the HSC at (a) $\mathrm{p}_{\text {Al-NPs }}=50 \mathrm{~nm},(\mathbf{b}) \mathrm{p}_{\text {Al-NPs }}=60 \mathrm{~nm},(\mathbf{c}) \mathrm{p}_{\mathrm{Al}-\mathrm{NPs}}=70 \mathrm{~nm}$, (d) $\mathrm{p}_{\text {Al-NPs }}=80 \mathrm{~nm}$, and (e) $\mathrm{p}_{\mathrm{Al}-\mathrm{NPs}}=90 \mathrm{~nm}$ in $\mathrm{y}-\mathrm{z}$ plane. $(\mathbf{f}-\mathbf{j})$ Electric field distribution of Al-NPs with different center spacing in the $x-y$ plane.

\section{Conclusions}

In this paper, the GaAs thickness and size of the solar cell, active layer thickness P3HT:PCBM, metal nanoparticles, and other structural parameters were studied. The mechanism of photon capture by P3HT:PCBM and the influence of surface plasmon on the solar cell were analyzed. Based on the above numerical simulation, we designed an optimal ultra-thin GaAs/P3HT:PCBM hybrid solar cell based on germanium substrate plasma plasmon. The broadband high absorption of this solar cell will allow further breakthroughs in this field. With the deepening of research and the continuous progress of technology, this type of solar cell will make greater progress and be widely used in the field of solar cells.

Author Contributions: X.Z.: Conceptualization, formal analysis, investigation, data curation, writingoriginal draft, writing-review and editing. N.S.: Conceptualization, formal analysis, investigation, data curation, funding acquisition. P.W.: Conceptualization, formal analysis, revision. All authors have read and agreed to the published version of the manuscript.

Funding: This research received no external funding.

Data Availability Statement: Not applicable.

Acknowledgments: This work is supported by the National Natural Science Foundation of China (11704223) and the Natural Science Foundation of Fujian Province (2020J01777, 2021J01972, 2021J05180).

Conflicts of Interest: The authors declare no conflict of interest.

\section{References}

1. Su, J.; Yang, H.; Xu, Y.; Tang, Y.; Yi, Z.; Zheng, F.; Zhao, F.; Liu, L.; Wu, P.; Li, H. Based on Ultrathin PEDOT: PSS/c-Ge Solar Cells Design and Their Photoelectric Performance. Coatings 2021, 11, 748. [CrossRef]

2. Deng, Y.; Cao, G.; Yang, H.; Zhou, X.; Wu, Y. Dynamic Control of Double Plasmon-Induced Transparencies in Aperture-Coupled Waveguide-Cavity System. Plasmonics 2018, 13, 345-352. [CrossRef]

3. Cheng, Z.; Liao, J.; He, B.; Zhang, F.; Zhang, F.; Huang, X.; Zhou, L. One-Step Fabrication of Graphene Oxide Enhanced Magnetic Composite Gel for Highly Efficient Dye Adsorption and Catalysis. ACS Sustain. Chem. Eng. 2015, 3, 1677-1685. [CrossRef]

4. Li, Y.; Li, M.; Xu, P.; Tang, S.; Liu, C. Efficient photocatalytic degradation of acid orange 7 over N-doped ordered mesoporous titania on carbon fibers under visible-light irradiation based on three synergistic effects. Appl. Catal. A Gen. 2016, 524, 163-172. [CrossRef]

5. Zhao, F.; Yi, Y.T.; Lin, J.C.; Yi, Z.; Qin, F.; Zheng, Y.; Liu, L.; Zheng, F.S.; Li, H.L.; Wu, P.H. The better photoelectric performance of thin-film $\mathrm{TiO}_{2}$ /c-Si heterojunctionsolar cells based on surface plasmon resonance. Results Phys. 2021, 28, 104628. [CrossRef] 
6. Zhao, F.; Lin, J.C.; Lei, Z.H.; Yi, Z.; Qin, F.; Zhang, J.G.; Liu, L.; Wu, X.W.; Yang, W.X.; Wu, P.H. Realization of $18.97 \%$ theoretical efficiency of $0.9 \mu \mathrm{m}$ Thick c-Si/ZnO Heterojunction Ultrathin-film Solar Cells via Surface Plasmon Resonance Enhancement. Phys. Chem. Chem. Phys. 2022. [CrossRef]

7. Chen, L.; Wang, Q.K.; Shen, X.Q.; Chen, W.; Huang, K.; Liu, D.M. Absorption enhancement in thin film a-Si solar cells with double-sided $\mathrm{SiO}_{2}$ particle layers. Chin. Phys. B 2015, 24, 104201. [CrossRef]

8. Pham, D.P.; Lee, S.; Yi, J.S. Potential high efficiency of GaAs solar cell with heterojunction carrier selective contact layers. Phys. B Phys. Condens. Matter 2021, 611, 412856. [CrossRef]

9. Ravinder, K.; Debiprasad, P.; Jhuma, S.; Sanowar, A.G.; Subhananda, C. Short-wave infrared (SWIR) photodetection by InAs/GaAs quantum dot heterostructures grown on Ge (100) substrate without Migration Enhanced Epitaxy layer. Superlattices Microstruct. 2020, 148, 106714. [CrossRef]

10. Yi, Z.; Li, J.; Lin, J.; Qin, F.; Chen, X.; Yao, W.; Liu, Z.; Cheng, S.; Wu, P.; Li, H. Broadband polarization-insensitive and wide-angle solar energy absorber based on tungsten ring-disc array. Nanoscale 2020, 12, 23077-23083. [CrossRef]

11. Yan, G.; Wang, J.L.; Liu, J.; Liu, Y.Y.; Wu, R.; Wang, R. Electroluminescence analysis of VOC degradation of individual subcell in GaInP/GaAs/Ge space solar cells irradiated by $1.0 \mathrm{MeV}$ electrons. J. Lumin. 2020, 219, 116905. [CrossRef]

12. Alcañiz, A.; López, G.; Martín, I.; Jiménez, A.; Datas, A.; Calle, E.; Ros, E.; Gerling, L.G.; Voz, C.; Cañizo, C.; et al. Germanium photovoltaic cells with MoOx hole-selective contacts. Sol. Energy 2019, 181, 357360. [CrossRef]

13. Siva, K.; Sukeerthi, M.; Suresh, E.P. Modeling of InGaP/InGaAs-GaAsP/Ge multiple quantum well solar cell to improve efficiency for space applications. Sol. Energy 2019, 186, 328-334. [CrossRef]

14. Ravinder, K.; Debiprasad, P.; Debabrata, D.; Arka, C.; Binita, T.; Jhuma, S.; Sourabh, U.; Raman, K.; Samir, K.P.; Subhananda, C. Realization of high-quality InGaAs/GaAs quantum dot growth on Ge substrate and improvement of optical property through ex-situ ion implantation. J. Lumin. 2020, 223, 117208. [CrossRef]

15. Richard, B.; Jay, M.; Change, W.; John, T.; Radek, R.; Chizmeshya, A.V.G.; Reid, J.; Sampriti, B.; Jose, M.; John, K. Comparative study of InGaAs integration on bulk Ge and virtual Ge/Si(100) substrates for low-cost photovoltaic applications. Sol. Energy Mater. Sol. Cells 2010, 94, 23622370. [CrossRef]

16. Zhang, W.N.; Tu, J.L.; Aierken, A.; Song, G.Y.; Xu, X.Z.; Yan, P.Y.; Sun, X.Y.; Hu, K.; Li, L.; Xu, P.Q. Effect of 1 MeV electron irradiation on $\mathrm{TiO}_{2} / \mathrm{Al}_{2} \mathrm{O}_{3} / \mathrm{MgF}_{2}$ anti-reflective coating for GaInP/InGaAs/Ge triple junction solar cells. Opt. Mater. 2020, 109, 110278. [CrossRef]

17. Zheng, Z.P.; Zheng, Y.; Luo, Y.; Yi, Z.; Zhang, J.G.; Liu, Z.M.; Yang, W.X.; Yu, Y.; Wu, X.W.; Wu, P. Switchable terahertz device combining ultra-wideband absorption and ultra-wideband complete reflection. Phys. Chem. Chem. Phys. 2022, 24, $2527-2533$. [CrossRef]

18. Li, J.; Jiang, J.; Xu, Z.; Liu, M.; Tang, S.; Yang, C.; Qian, D. Facile synthesis of Ag@Cu $\mathrm{C}_{2} \mathrm{O}$ heterogeneous nanocrystals decorated $\mathrm{N}$-doped reduced graphene oxide with enhanced electrocatalytic activity for ultrasensitive detection of $\mathrm{H}_{2} \mathrm{O}_{2}$. Sens. Actuators $B$ Chem. 2018, 260, 529-540. [CrossRef]

19. Tang, N.; Li, Y.; Chen, F.; Han, Z. In situ fabrication of a direct Z-scheme photocatalyst by immobilizing CdS quantum dots in the channels of graphene-hybridized and supported mesoporous titanium nanocrystals for high photocatalytic performance under visible light. RSC Adv. 2018, 8, 42233-42245. [CrossRef]

20. Cai, R.; Rao, W.; Zhang, Z.; Long, F.; Yin, Y. An imprinted electrochemical sensor for bisphenol A determination based on electrodeposition of a graphene and Ag nanoparticle modified carbon electrode. Anal. Methods 2014, 6, 1590-1597. [CrossRef]

21. Liu, Y.; Bo, M.; Yang, X.; Zhang, P.; Sun, C.Q.; Huang, Y. Size modulation electronic and optical properties of phosphorene nanoribbons: DFT-BOLS approximation. Phys. Chem. Chem. Phys. 2017, 19, 5304-5309. [CrossRef] [PubMed]

22. Lv, P.; Xie, D.; Zhang, Z. Magnetic carbon dots based molecularly imprinted polymers for fluorescent detection of bovine hemoglobin. Talanta 2018, 188, 145-151. [CrossRef] [PubMed]

23. Pala, R.A.; White, J.; Barnard, E.; Liu, J.; Brongersma, M.L. Design of plasmonic thin-film solar cells with broadband absorption enhancements. Adv. Mater. 2009, 21, 3504-3509. [CrossRef]

24. Li, Z.; Yi, Y.; Xu, D.; Yang, H.; Yi, Z.; Chen, X.; Yi, Y.; Zhang, J.; Wu, P. A multi-band and polarization-independent perfect absorber based on Dirac semimetals circles and semi-ellipses array. Chin. Phys. B 2021, 30, 098102. [CrossRef]

25. Abhijith, T.N.; Shamjid, P.; Reddy, V.S. Multi-positional silver nanostructures for high absorption enhancement in polymer solar cells. Org. Electron. 2019, 73, 311-316. [CrossRef]

26. Yu, A.A.; Ostrikov, K.; Li, E.P. Surface Plasmon Enhancement of Optical Absorption in Thin-Film Silicon Solar Cells. Plasmonics 2009, 4, 107-113. [CrossRef]

27. Zheng, Z.P.; Zheng, Y.; Luo, Y.; Yi, Z.; Zhang, J.G.; Liu, L.; Song, Q.J.; Wu, P.H.; Yu, Y.; Zhang, J.F. Terahertz perfect absorber based on flexible active switching of ultra-broadband and ultra-narrowband. Opt. Express 2021, 29, 42787-42799. [CrossRef]

28. Jiang, L.; Yi, Y.; Tang, Y.; Li, Z.; Yi, Z.; Liu, L.; Chen, X.; Jian, R.; Wu, P.; Yan, P. A high quality factor ultra-narrow band perfect metamaterial absorber for monolayer molybdenum disulfide. Chin. Phys. B 2022, 31, 038101. [CrossRef]

29. Zhou, F.; Qin, F.; Yi, Z.; Yao, W.-T.; Liu, Z.; Wu, X.; Wu, P. Ultra-wideband and wide-angle perfect solar energy absorber based on Ti nanorings surface plasmon resonance. Phys. Chem. Chem. Phys. 2021, 23, 17041-17048. [CrossRef]

30. Ding, D.; Yang, S.E.; Chen, Y.S.; Gao, X.Y.; Gu, J.H.; Lu, J.X. Restructuring of plasmonic nanoparticle aggregates with arbitrary particle size distribution in pulsed laser fields. Acta Phys. Sin. 2015, 64, 248801. [CrossRef] 
31. Chaudhuri, R.G.; Paria, S. Core/shell nanoparticles: Classes, properties, synthesis mechanisms, characterization, and applications. Chem. Rev. 2012, 112, 2373-2433. [CrossRef] [PubMed]

32. Singh, G.; Verma, S.S. Design and analysis of thin film GaAs solar cells using silver nanoparticle plasmons. Photonics Nanostruc. Fundam. Appl. 2019, 37, 100731. [CrossRef]

33. Liu, X.L.; Xuan, Y.M. Defects-assisted solar absorption of plasmonic nanoshell-based nanofluids. Sol. Energy 2017, 146, 503-510. [CrossRef]

34. Gurjit, S.; Jagmeet, S.S.; Verma, S.S. Cu Nanoparticle Plasmons to Enhance GaAs Solar Cell Efficiency. In Proceedings of the 13th International Conference on Fiber Optics and Photonics, Kanpur, India, 4-8 December 2016. [CrossRef]

35. Gurjit, S.; Verma, S.S. Plasmon enhanced light trapping in thin film GaAs solar cells by Al nanoparticle array. Phys. Lett. A 2019, 383, 1526-1530. [CrossRef]

36. Shi, L.X.; Zhou, Z.; Huang, Z.G. The influence of silver core position on enhanced photon absorption of single nanowire $\alpha$-Si solar cells. Opt. Express 2013, 21, A1007-A1017. [CrossRef] [PubMed]

37. Wu, X.; Zheng, Y.; Luo, Y.; Zhang, J.; Yi, Z.; Wu, X.; Cheng, S.; Yang, W.; Yu, Y.; Wu, P. A four-band and polarization-independent BDS-based tunable absorber with high refractive index sensitivity. Phys. Chem. Chem. Phys. 2021, 23, 26864-26873. [CrossRef]

38. Yee, K. Numerical solution of initial boundary value problems involving Maxwell's equations in isotropic media. IEEE Trans. Antennas Propag. 1966, 14, 302-307. [CrossRef]

39. Cao, G.; Li, H.; Deng, Y.; Zhan, S.; He, Z.; Li, B. Systematic Theoretical Analysis of Selective-Mode Plasmonic Filter Based on Aperture-Side-Coupled Slot Cavity. Plasmonics 2014, 9, 1163-1169. [CrossRef]

40. Long, F.; Zhang, Z.; Wang, J.; Yan, L.; Zhou, B. Cobalt-nickel bimetallic nanoparticles decorated graphene sensitized imprinted electrochemical sensor for determination of octylphenol. Electrochim. Acta 2015, 168, 337-345. [CrossRef]

41. Chen, H.-J.; Zhang, Z.-H.; Cai, R.; Kong, X.-Q.; Chen, X.; Liu, Y.-N.; Yao, S.-Z. Molecularly imprinted electrochemical sensor based on a reduced graphene modified carbon electrode for tetrabromobisphenol A detection. Analyst 2013, 138, 2769-2776. [CrossRef]

42. Lin, X.; Li, Y.J.; Chen, F.T.; Xu, P.; Li, M. Facile synthesis of mesoporous titanium dioxide doped by Ag-coated graphene with enhanced visible-light photocatalytic performance for methylene blue degradation. RSC Adv. 2017, 7, 25314-25324. [CrossRef]

43. Li, J.; Chen, X.; Yi, Z.; Yang, H.; Tang, Y.; Yi, Y.; Yao, W.; Wang, J.; Yi, Y. Broadband solar energy absorber based on monolayer molybdenum disulfide using tungsten elliptical arrays. Mater. Today Energy 2020, 16, 100390. [CrossRef]

44. Cai, L.; Zhang, Z.; Xiao, H.; Chen, S.; Fu, J. An eco-friendly imprinted polymer based on graphene quantum dots for fluorescent detection of p-nitroaniline. RSC Adv. 2019, 9, 41383-41391. [CrossRef]

45. Cheng, T.T.; Gao, H.J.; Liu, G.R.; Pu, Z.S.; Wang, S.F.; Yi, Z.; Wu, X.W.; Yang, H. Preparation of core-shell heterojunction photocatalysts by coating $\mathrm{CdS}$ nanoparticles onto $\mathrm{Bi}_{4} \mathrm{Ti}_{3} \mathrm{O}_{12}$ hierarchical microspheres and their photocatalytic removal of organic pollutants and $\mathrm{Cr}(\mathrm{VI})$ ions. Colloids Surf. A Physicochem. Eng. Asp. 2021, 633, 127918. [CrossRef]

46. Deng, Y.; Cao, G.; Wu, Y.; Zhou, X.; Liao, W. Theoretical Description of Dynamic Transmission Characteristics in MDM Waveguide Aperture-Side-Coupled with Ring Cavity. Plasmonics 2015, 10, 1537-1543. [CrossRef]

47. Zhang, Z.; Cai, R.; Long, F.; Wang, J. Development and application of tetrabromobisphenol A imprinted electrochemical sensor based on graphene/carbon nanotubes three-dimensional nanocomposites modified carbon electrode. Talanta 2015, 134, 435-442. [CrossRef]

48. Li, J.; Jiang, J.; Zhao, D.; Xu, Z.; Liu, M.; Liu, X.; Tong, H.; Qian, D. Novel hierarchical sea urchin-like Prussian blue@palladium core-shell heterostructures supported on nitrogen-doped reduced graphene oxide: Facile synthesis and excellent guanine sensing performance. Electrochim. Acta 2020, 330, 135196. [CrossRef]

49. Chen, P.; Liu, F.; Ding, H.; Chen, S.; Chen, L.; Li, Y.-J.; Au, C.-T.; Yin, S.-F. Porous double-shell CdS@C3N4 octahedron derived by in situ supramolecular self-assembly for enhanced photocatalytic activity. Appl. Catal. B Environ. 2019, 252, 33-40. [CrossRef]

50. Zhao, F.; Chen, X.F.; Yi, Z.; Qin, F.; Tang, Y.J.; Yao, W.T.; Zhou, Z.G.; Yi, Y.G. Study on the solar energy absorption of hybrid solar cells with trapezoid-pyramidal structure based PEDOT: PSS/c-Ge. Sol. Energy 2020, 204, 635-643. [CrossRef]

51. Liu, H.; Wang, Q.; Zhang, F. Preparation of $\mathrm{Fe}_{3} \mathrm{O}_{4} @ \mathrm{SiO}_{2} @ \mathrm{P}(\mathrm{AANa}-\mathrm{Co}-\mathrm{AM})$ composites and their adsorption for Pb (II). ACS Omega 2020, 5, 8816-8824. [CrossRef]

52. Yang, X.; Zhang, F.; Hu, Y.J.; Chen, D.Z.; He, Z.Q.; Xiong, L.Z. Gold nanoparticals doping graphene sheets nanocomposites sensitized screen-printed carbon electrode as a disposable platform for voltammetric determination of guaiacol in bamboo juice. Int. J. Electrochem. Sci. 2014, 9, 5061-5072.

53. Jiang, L.Y.; Yi, Y.T.; Yi, Z.; Yang, H.; Li, Z.Y.; Su, J.; Zhou, Z.G.; Chen, X.F.; Yi, Y.G. A four-band perfect absorber based on high quality factor and high figure of merit of monolayer molybdenum disulfide. Acta Phys. Sin. 2021, 70, 128101. [CrossRef] 